\title{
FAILURE ANALYSIS OF REAR AXLE (BANJO BEAM) HOUSING OF A UTILITY VEHICLE
}

\author{
Shivani Jog \\ PG Student, Mechanical Engineering Department, Gokhale Education Society's, \\ R.H. Sapat, College of Engineering, Nashik, India
}

\section{Dr. Prashant Nehe}

Associate Professor, Mechanical Engineering Department, Gokhale Education Society's, R.H. Sapat, College of Engineering, Nashik, India

\begin{abstract}
This paper describes the failure analysis of a rear axle housing used in a utility vehicle. This vehicle had been involved in an accident. The rear axle shaft housing was found broken into two pieces. In present study utility vehicle rear axle housing was selected to study the failure analysis experimentally and numerically. The failed rear axle housing was undertaken to check its integrity which includes visual examination, chemical analysis, photo documentation, micro hardness test, and metallographic tests to evaluate the failure. Failure analysis of a rear axle housing used in a utility vehicle was studied to determine stress concentration area. Based on field study strain gauges are mounted on failed parts to determine stress intensity and joint analysis were validated with Finite Element Analysis results.

SEM (scanning electron microscope was used to examine the failure zones. The analysis showed that the rear axle housing suffered a fatigue induced fracture. The fracture initiated at the weld joint between back plate and rear axle housing, where a stress concentration was created. This stress concentration was higher than the stress concentration considered at the time of design which results into the breakage of the housing into two parts. Also stress concentration was found more on left side as compared with right side. Hence, all the reported failures were broken on the left side only. So, the causes of the failure of the rear axle housing was due to defective geometric design of the rear axle housing. To avoid this failure in future the axle housing thickness is changed from $3.5 \mathrm{~mm}$ to $4 \mathrm{~mm}$. This design change sustained the high stress concentration which was analysed with the help of finite element analysis.
\end{abstract}

Key words: Failure Analysis, Finite Element Analysis, Rear axle, Rear axle Housing. 
Cite this Article: Shivani Jog and Prashant Nehe, Failure Analysis of Rear Axle (Banjo Beam) housing of a Utility Vehicle. International Journal of Design and Manufacturing Technology 11(1), 2020, pp. 1-14.

https://iaeme.com/Home/issue/IJDMT?Volume $=10 \&$ Issue $=1$

\section{INTRODUCTION}

An axle is a cross member supporting a vehicle, on which one or more wheels turn. Axle shaft connects the two wheels in a vehicle. Axle shaft usually extends from opposite sides of a differential gear box and provided at their outer wheel ends with integral or otherwise rigid drive flanges which are connected to the wheels for transmission of driving power [1]. An axle assembly on a vehicle is the set of components that allows the wheels to rotate freely. Axle sits inside an axle housing. It is held in place by bearings or bushings that allows it to rotate within the axle housing. Axle housing also supports in lubrication of the rotating axle.

Axle housing is non- rotating member and carry the suspension seats over which the suspension springs are mounted. They are subjected to dynamic inertial loads as the vehicle moves over an uneven road surface and hence are predominantly subjected to bending during service. Bending moment distribution of rear axle housing's schematic diagram, is shown in Fig. 1.
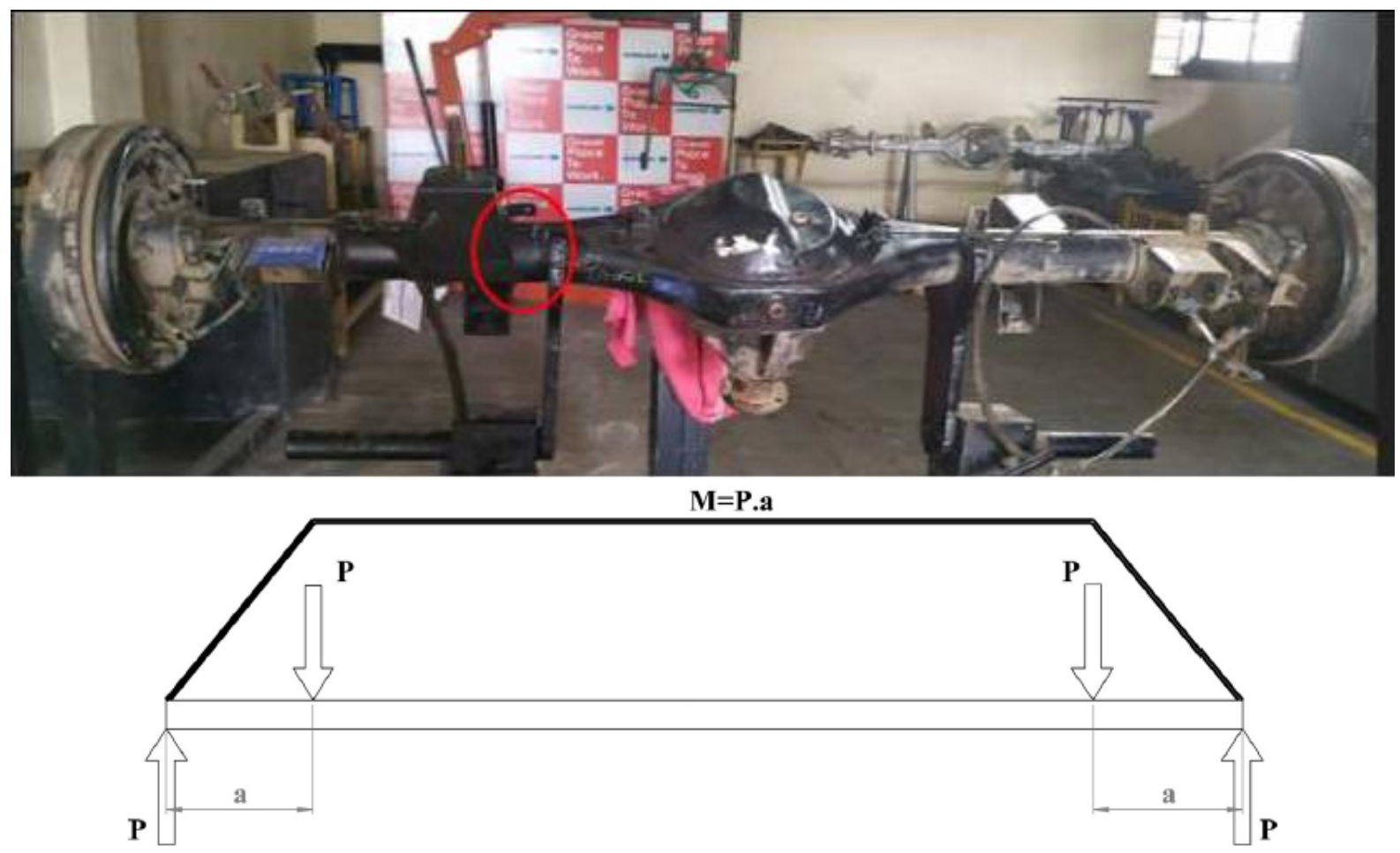

Figure 1 Bending moment distribution on rear axle housing

Research on failure analysis of various components has been carried out over the years. S. P. Raut and L.R. Raut [1] reviewed the various methodology used for failure analysis of shaft used in different application. The researchers discussed various tools and techniques used for analysis such as, non destructive testing, optical microscope, scanning electron microscopy, energy dispersive X-ray spectroscopy, heat affected zone, hardness testing instruments, fatigue testing, tensile testing, etc. Souvik Das et al. [2] carried out failure analysis of axle shaft of a fork lift which was failed at operation within 296 hours of service. They suggested that the fracture was initiated from the martensitic case as brittle mode due to improper heat 
treatment process and inclusions along the longitudinal axis made the component more prone to failure.

Khairul Akmal et al. [3] reviewed premature failure that occurred due to the higher loading capacity of the heavy vehicle. New design of rear axle model was developed by increasing the thickness of sheet by $7 \mathrm{~mm}$ to increase the fatigue life of the housing to increase the rigidity of the axle housing.F Mujahidin et al [4] reviewed the axle shaft. Their findings showed that the failure was not due to material factors but the failure occurred due to a large enough momentary shock load.

G.K. Nanawarea, et al[5] reviewed the rear axle shafts of 575 DI tractors manufactured by Mahindra and Mahindra Ltd, Tractor Division, Mumbai and found that it failed before completion of warranty period. Inadequate spline root radius resulted into the failure of rear axle shafts, which results into subsequent crack growth and crack initiation was by fatigue under the cyclic loading conditions of field operation. Osman Asi [6] has done the failure analysis of a rear axle shaft used in an automobile. Results suggest that the axle shaft fractured while reversed bending fatigue because of improper welding. M.M Topac, et al.[7] reviewed a premature failure that occurs prior to the expected load cycles during the vertical fatigue tests of a rear axle housing prototype.

The objective of this paper is to investigate, analyse the root cause of the sudden failure of a rear axle housing in a running condition and to found the solution to avoid this kind of failures in future. Root cause analysis was carried out using experimental analysis and with combination of experimental and finite element analysis, solution and recommendation is proposed. Fig. 2 shows the actual fracture of the rear axle housing.

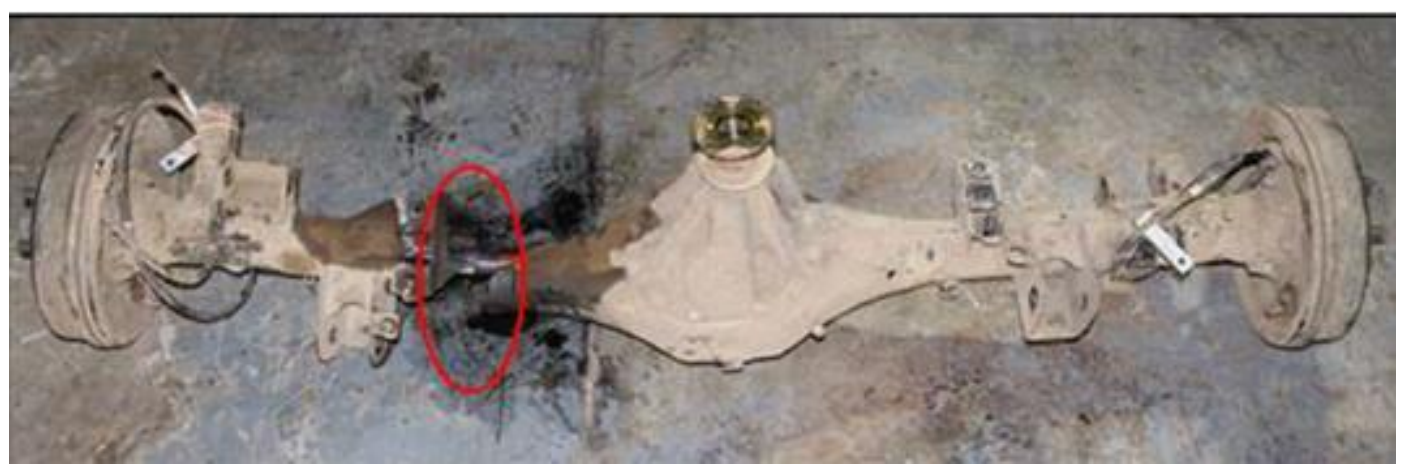

Figure 2 Fracture of the Rear Axle housing at the left side

\section{EXPERIMENTAL ANALYSIS OF REAR AXLE HOUSING}

The failed rear axle housing was collected from the field for analysis. The sample was cleaned with acetone to remove dirt to perform visual examination. After that the sample was prepared for metallographic analysis. Transverse specimen was made from the cut section end of the failed rear axle housing for conducting Optical Emission Microscopic examination. The sample was polished by standard metallographic techniques to produce scratch free surface. The polished sample was etched in 3\% Nital solution ( $3 \mathrm{ml}$ nitric acid and $97 \mathrm{ml}$ ethyl alcohol), and etched as well as un etched samples were examined under an Optical Emission Microscope. The hardness of the different location of rear axle housing was measured in Vickers harness tester. A $50 \mathrm{kgf}$ of load was applied during testing, and a few numbers of indentations were made to measure the harness of the rear axle housing.

Experimental investigation includes following analysis of the failed rear axle housing- 
- Visual Analysis

- Metallographic \& Chemical Analysis

- Hardness measurement.

\subsection{Visual Inspection}

Beam housing / rear axle housing failed from left side $\&$ fractured into two pieces from the end of weld joint of the back plate \& beam housing. Fracture initiated from the end of seam weld on back plate at 13 to $14 \mathrm{~mm}$ below tube seam weld. At fracture initiation, clear beach marks are observed. No hit or dent mark or other damage were found near fracture initiation. Fracture can be determined as brittle when the surface seen flat, mixture of ductile and brittle when surface has moderate degree of roughness, ductile when surface is more on rough side. Broken component shows moderate degree of roughness, so it must be combination of ductile and brittle type of fracture. As shown in Fig. 3.

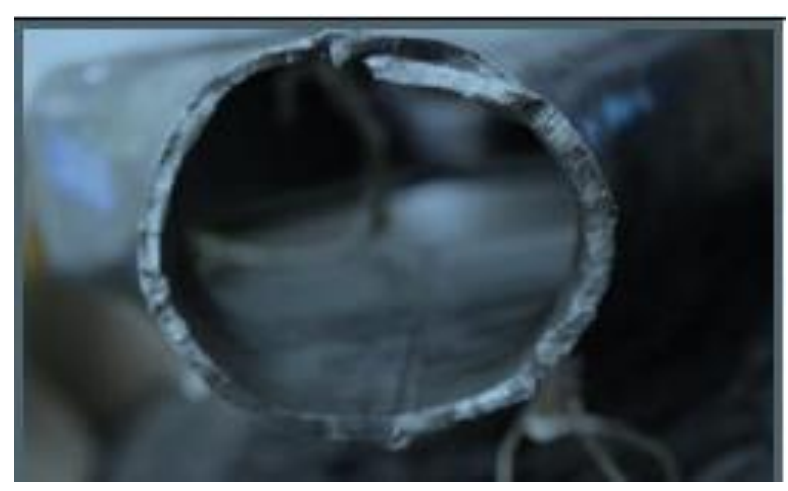

Figure 3 Broken piece of rear axle housing

\subsection{Metallographic Analysis}

Fig. 4 explains in detail about the approximate magnification ranges from instruments used to study the fracture surfaces and microstructure. It shows that till x10 magnification, hand lenses can be used. For x10 to x100, stereo microscope is helpful. To study between x100 to x1000 optical microscope is used. Scanning electron microscope can be used to study from $\mathrm{x} 10$ to less than $\mathrm{x} 100000$ and transmission electron microscope can give magnification from greater than $\times 100$ to $x 100000$. Based on the application and detail requirement, instrument can be selected to do the analysis.

In this paper for the analysis scanning electron microscope is used.

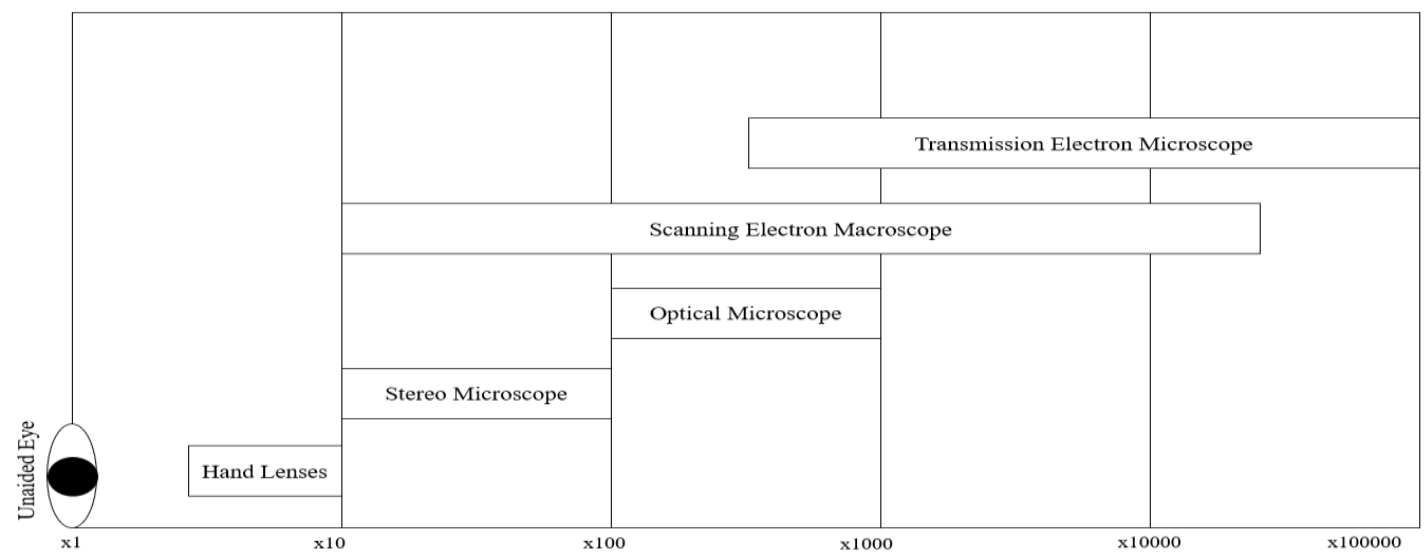

Figure 4 Approximate magnification ranges for instruments used to study the fracture surfaces and microstructure 
Table 1 Chemical composition of the rear axle housing

\begin{tabular}{|c|c|c|c|c|c|c|}
\hline Specification & C\% & Mn\% & P\% & S\% & Si\% & Al\% (min) \\
\hline BSK-46 & 0.12 & 1.4 & 0.03 & 1.03 & 0.1 & $0.3 \max$ \\
\hline $\begin{array}{c}\text { Actual } \\
\text { Percentage }\end{array}$ & 0.11 & 1.18 & 0.01 & 0.02 & 0.04 & 0.02 \\
\hline
\end{tabular}

Table 1 Actual chemical composition of the rear axle housing with respect to the specified composition [8]

Table 1 shows, the chemical composition of the failed axle housing containing $0.11 \%$ Carbon, 1.18\% Manganese, 0.01\% Phosphorus, 0.02\% Sulphur, 0.04\% Silicon and 0.02\% Aluminium. Whereas raw material BSK-46 contains 0.12\% Carbon, $1.4 \%$ Manganese, $0.03 \%$ Phosphorous, $1.03 \%$ Sulphur, 0.1\% Silicon, and 0.3\% max Aluminium [8]. Failed component material is BSK-46 only as indicated by the observed values. Hence, no deviation is observed in the raw material. Therefore, the failure is not attributed to improper raw material. According to chemical composition analysis by Optical Emission Spectroscope, the rear axle housing was manufactured using BSK-46[8].

Metallographic microstructure is shown in Fig.5 for the rear axle housing. It shows an element mainly formed by uniformly distributed ferrite \& perlite. The presence of uniform perlite indicates that the material suffered a heat treatment of quenching $\&$ tempering.

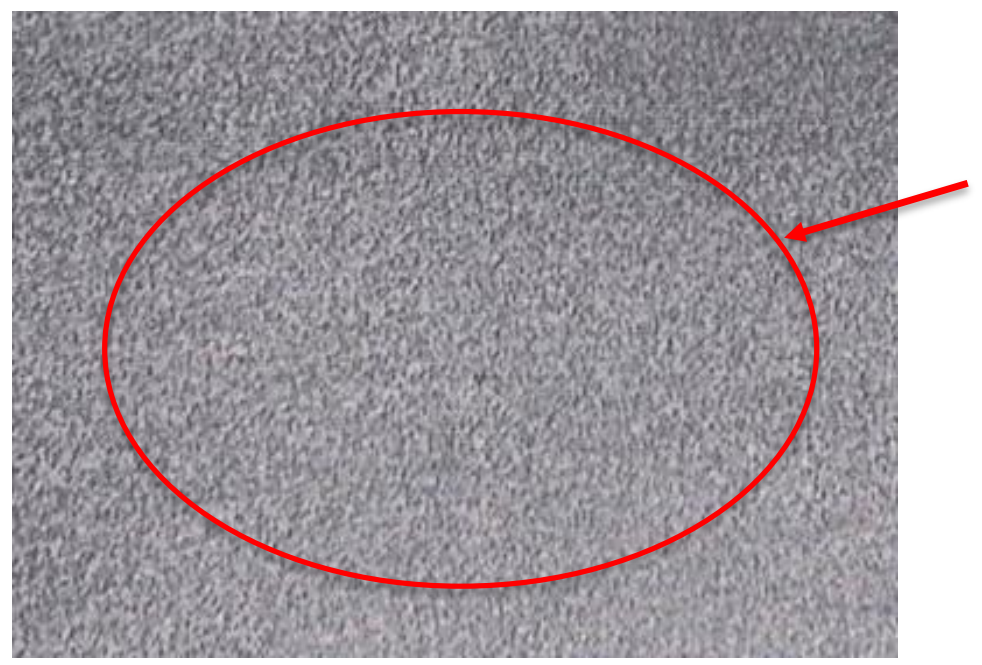

\section{Uniform distribution of ferrite \& perlite.}

Figure 5 Microstructure of the material. Etched with Nital 3\%

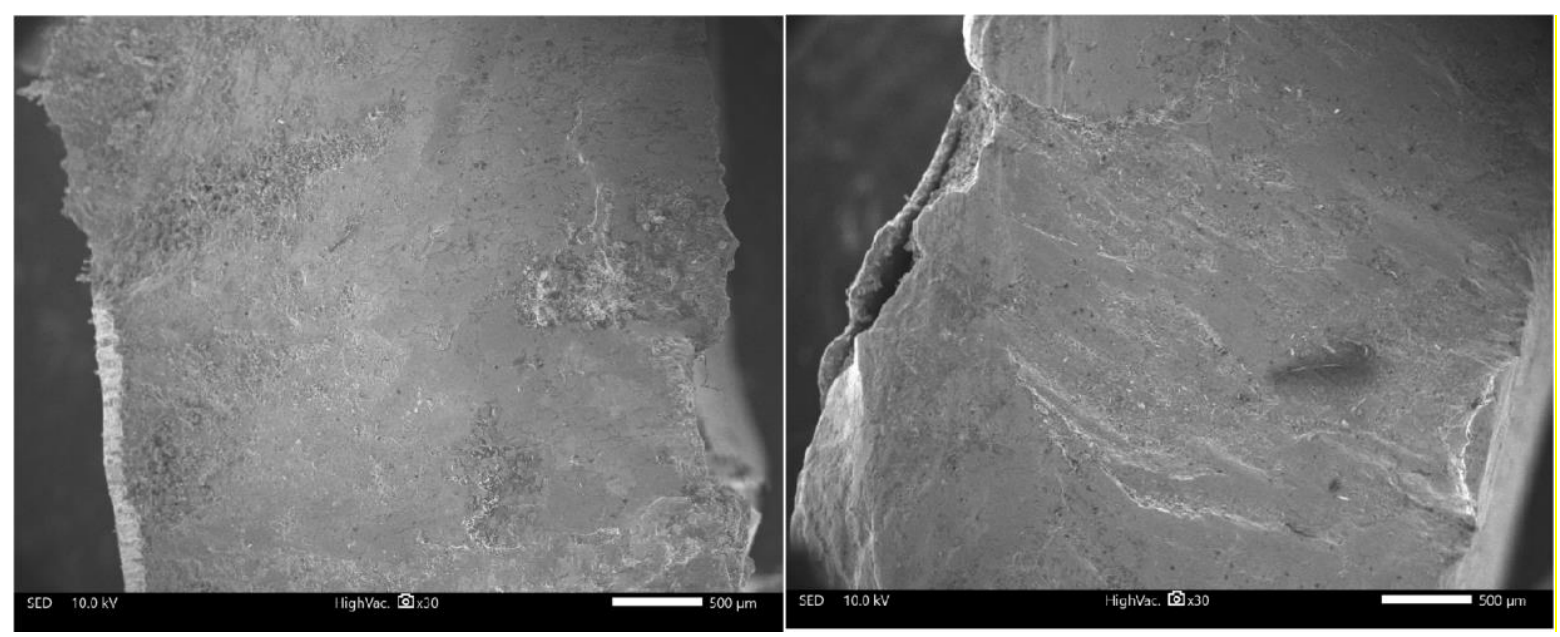



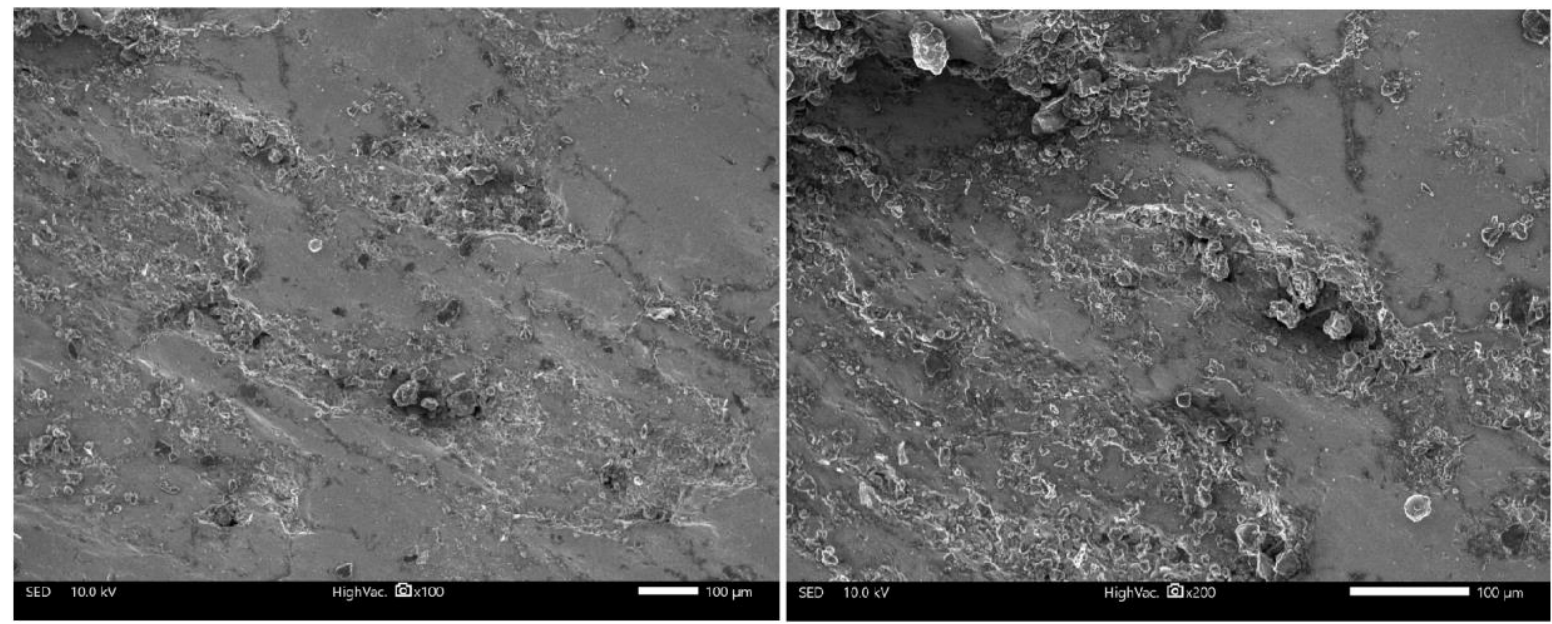

Figure 6 Specimen under different magnification under Scanning Electron Macroscope (SEM).

SEM (scanning electron microscope) was used to examine the fractured surface in order to characterize the fracture micro mechanism. Fig. 6 shows the specimen at different magnification. The fracture surface contains ratchet marks. The ratchet marks indicate multiple origins and relatively high total stresses. Ratchet marks can result from high stress on the part or from high-stress concentrations. The combination of many ratchet marks and a small overload zone indicates that the load was light, but there were high stress concentrations. From these observations, it is clear that fatigue cracks have initiated at stress concentration points leading to fracturing of the rear axle housing. The badly welded region can lead to a high-stress concentration, but can also cause fatigue crack initiation during short service time. A fatigue crack has possibility to form when the local stress exceeds the material yield strength. Since steel resistance to fatigue initiation, is proportional to its yield strength, the low properties of the steel left it open to fatigue initiation. The area of final overload fracture is small, approximately $15 \%$ of total area, indicating that the material was adequate for the applied stresses. Fig. 6 shows specimen under 30X magnification having flat as well as moderate roughness, which indicates material is mixture of both ductile as well as brittle failure.

\subsection{Vickers Hardness Study}

Vickers hardness study were performed using a $50 \mathrm{kgf}$ load with 13 second dwell time on location back plate to beam housing weld. Table 2 shows Vickers hardness test results.

Table 2 shows, there was no deviation in material thickness, leg length, maximum weld nugget hardness, concavity, maximum heat affected zone harness. Hence, weld parameter of the components was within specification as per ES-PS-0522[9]. It indicates no issue in weld parameter of components. 
Table 2 Vickers hardness test results

\begin{tabular}{|c|c|c|c|}
\hline Weld Parameters & $\begin{array}{c}\text { Beam housing to weld } \\
\text { (near fracture } \\
\text { initiation) }\end{array}$ & $\begin{array}{c}\text { Backing plate to weld } \\
\text { (near fracture } \\
\text { initiation) }\end{array}$ & Specified per ES-PS-0522 \\
\hline $\begin{array}{c}\text { Actual wall } \\
\text { thickness (mm) }\end{array}$ & 3.5 & 3.5 & $\begin{array}{c}\text { Beam Hsg.: } 3.5+-0.127 \mathrm{~mm} \\
\text { Backing plate: } 3.5+- \\
0.127 \mathrm{~mm}\end{array}$ \\
\hline Leg length (mm) & 3.7 & 3.1 & $\begin{array}{c}2.10-7.93 \mathrm{~mm} \\
(0.6 \text { X Thickness of thinnest } \\
\text { member) }\end{array}$ \\
\hline $\begin{array}{c}\text { Effective Throat } \\
\text { (mm) }\end{array}$ & \multicolumn{2}{|c|}{1.91} & $\begin{array}{c}2.10-7.93 \mathrm{~mm} \text { (Equal to } \\
\text { Minimum Leg Length) }\end{array}$ \\
\hline $\begin{array}{c}\text { Maximum weld } \\
\text { nugget hardness } \\
\text { (HV) }\end{array}$ & 295 & 354 HV Ma \\
\hline Concavity (mm) & 231 & 167 & $0.8 \mathrm{~mm} \mathrm{Max}$ \\
\hline $\begin{array}{c}\text { Maximum heat } \\
\text { affected zone } \\
\text { hardness (HV) }\end{array}$ & 211 & 214 & \begin{tabular}{c}
$446 \mathrm{HV}$ Max \\
\hline $\begin{array}{c}\text { Parent material } \\
\text { hardness }\end{array}$
\end{tabular} \\
\hline
\end{tabular}

\subsection{Weld Evaluation Analysis}

Weld evaluation analysis study was performed on the component by taking various sections to understand the weld quality. Table 3 shows, backing plate to beam housing weld quality test results and Table 4 shows, backing plate to beam housing cut section analysis results. fig. 7 shows the different sections taken for the analysis with the help of red dotted line.

Fracture shows high cycle bending fatigue type failure along beam axis. Probable cause of premature weld failure seems to be high stresses coming at weld joints during application.

Table 3 Backing plate to beam housing weld quality

\begin{tabular}{|c|c|c|}
\hline \multirow{2}{*}{ Locations } & \multicolumn{2}{|c|}{ Weld Region Hardness (HV) } \\
\cline { 2 - 3 } & $\begin{array}{c}\text { Beam housing to weld (near } \\
\text { fracture initiation) }\end{array}$ & $\begin{array}{c}\text { Back plate to weld (near fracture } \\
\text { initiation) }\end{array}$ \\
\hline \multirow{3}{*}{ Parent } & 211 & 134 \\
\cline { 2 - 3 } & 214 & 139 \\
\cline { 2 - 3 } & - & 137 \\
\hline \multirow{3}{*}{ Heat affected zone (HAZ) } & 227 & 158 \\
\cline { 2 - 3 } & 231 & 163 \\
\cline { 2 - 3 } & - & 167 \\
\hline \multirow{3}{*}{ Weld nugget } & \multicolumn{2}{|c|}{288} \\
\cline { 2 - 3 } & \multicolumn{2}{|c|}{293} \\
\cline { 2 - 3 } & \multicolumn{2}{|c|}{} \\
\cline { 2 - 3 }
\end{tabular}

Table 3 shows detailed analysis of weld quality. It indicates that weld quality is as per specification as the weld region hardness is less than $446 \mathrm{HV}$ [5]. 
Table 4 Backing plate to beam housing weld quality

\begin{tabular}{|c|c|c|c|c|c|}
\hline \multirow[b]{2}{*}{ Locations } & \multirow[b]{2}{*}{$\begin{array}{c}\text { Specification per ES } \\
\text { - PS - 0522 }\end{array}$} & \multicolumn{4}{|c|}{ Weld quality Case - 1} \\
\hline & & $\begin{array}{c}\text { Cut section } 2 \\
\text { location A at } \\
\text { linear weld } \\
\text { beam housing } \\
\text { to weld }\end{array}$ & $\begin{array}{c}\text { Cut section } 2 \\
\text { location B at back } \\
\text { plate to lower half } \\
\text { beam housing to } \\
\text { weld }\end{array}$ & $\begin{array}{c}\text { Cut section } 3 \\
\text { at linear weld } \\
\text { beam housing } \\
\text { to weld }\end{array}$ & $\begin{array}{c}\text { Cut section } 4 \\
\text { at linear weld } \\
\text { beam housing } \\
\text { to weld }\end{array}$ \\
\hline $\begin{array}{c}\text { Actual wall } \\
\text { thickness (mm) }\end{array}$ & $\begin{array}{c}\text { Beam Hsg.: } 3.5+- \\
0.127 \mathrm{~mm} \\
\text { Backing plate: } 3.5+- \\
0.127 \mathrm{~mm}\end{array}$ & 3.5 & 3.5 & 3.5 & 3.5 \\
\hline \multirow{2}{*}{ Leg length (mm) } & \multirow{2}{*}{$\begin{array}{c}2.10-7.93 \mathrm{~mm}(0.6 \\
\text { X Thickness of } \\
\text { thinnest member) } \\
\end{array}$} & 5.3 & 3.16 & 4.5 & 4.7 \\
\hline & & 4.8 & 2.7 & 3.9 & 4.5 \\
\hline $\begin{array}{c}\text { Effective throat } \\
(\mathrm{mm}) \text { max weld } \\
\text { nugget hardness } \\
(\mathrm{HV})\end{array}$ & $\begin{array}{c}2.10-7.93 \mathrm{~mm} \\
\text { (Equal to minimum } \\
\text { leg length) }\end{array}$ & 2.44 & 2.6 & 2.165 & 2.3 \\
\hline $\begin{array}{c}\text { Penetration for } \\
\text { seam joint }\end{array}$ & $60 \% \min$ & 69.8 & 15.1 & 61.85 & 64.3 \\
\hline Concavity & $0.8 \mathrm{~mm} \max$ & NA & Not obs & NA & NA \\
\hline $\begin{array}{l}\text { Max heat affected } \\
\text { zone hardness }(\mathrm{HV})\end{array}$ & $\begin{array}{c}83 \mathrm{Max}(446 \mathrm{HV} \\
\operatorname{max.})\end{array}$ & 193 & 177 & 186 & 179 \\
\hline $\begin{array}{c}\text { Parent material } \\
\text { hardness }\end{array}$ & $\begin{array}{c}79-91 \text { HRB }(147- \\
190 \mathrm{HV})\end{array}$ & 193 & 186 & 190 & 179 \\
\hline
\end{tabular}

\begin{tabular}{|c|c|c|c|c|c|}
\hline \multirow[b]{2}{*}{ Locations } & \multirow[b]{2}{*}{$\begin{array}{c}\text { Specification per ES } \\
\text { - PS - 0522 }\end{array}$} & \multicolumn{4}{|c|}{ Weld Quality Case - 2} \\
\hline & & $\begin{array}{c}\text { Cut section } 1 \\
\text { location A1 at } \\
\text { linear weld } \\
\text { beam housing } \\
\text { to weld }\end{array}$ & $\begin{array}{c}\text { Cut section } 1 \\
\text { location A2 at } \\
\text { back plate to } \\
\text { lower half beam } \\
\text { housing to weld }\end{array}$ & $\begin{array}{c}\text { Cut section } 1 \\
\text { location B1 at } \\
\text { linear weld \& } \\
\text { back plate } \\
\text { beam housing } \\
\text { to weld }\end{array}$ & $\begin{array}{c}\text { Cut section } 1 \\
\text { location B2 at } \\
\text { back plate to } \\
\text { lower half } \\
\text { beam housing } \\
\text { to weld }\end{array}$ \\
\hline $\begin{array}{c}\text { Actual wall } \\
\text { thickness (mm) }\end{array}$ & $\begin{array}{c}\text { Beam Hsg.: } 3.5+- \\
0.127 \mathrm{~mm} \\
\text { Backing plate: } 3.5+- \\
0.127 \mathrm{~mm}\end{array}$ & 3.5 & 3.5 & 3.5 & 3.5 \\
\hline \multirow{2}{*}{ Leg length (mm) } & \multirow{2}{*}{$\begin{array}{c}2.10-7.93 \mathrm{~mm}(0.6 \\
\text { X Thickness of } \\
\text { thinnest member })\end{array}$} & 4.8 & 5.4 & 5.2 & 3.2 \\
\hline & & 5.9 & 3.5 & 5.3 & 2.2 \\
\hline $\begin{array}{c}\text { Effective throat } \\
(\mathrm{mm}) \text { max weld } \\
\text { nugget hardness } \\
(\mathrm{HV}) \\
\end{array}$ & $\begin{array}{c}2.10-7.93 \mathrm{~mm} \\
\text { (Equal to minimum } \\
\text { leg length) }\end{array}$ & 2.4 & 4.2 & 3.1 & 3.43 \\
\hline $\begin{array}{c}\text { Penetration for } \\
\text { seam joint }\end{array}$ & $60 \% \min$ & 68.4 & 41.11 & 87.9 & 20.74 \\
\hline Concavity & $0.8 \mathrm{~mm} \max$ & NA & Not obs & NA & Not obs \\
\hline $\begin{array}{l}\text { Max heat affected } \\
\text { zone hardness (HV) }\end{array}$ & $\begin{array}{c}83 \mathrm{Max}(446 \mathrm{HV} \\
\text { max.) }\end{array}$ & 168 & 191 & 189 & 186 \\
\hline $\begin{array}{c}\text { Parent material } \\
\text { hardness }\end{array}$ & $\begin{array}{c}79-91 \text { HRB }(147- \\
190 \mathrm{HV})\end{array}$ & 178 & 187 & 178 & 187 \\
\hline
\end{tabular}

Table 4 Shows that, weld quality of the failed component was within the specified range as per ES-PS-0522 [5]. 


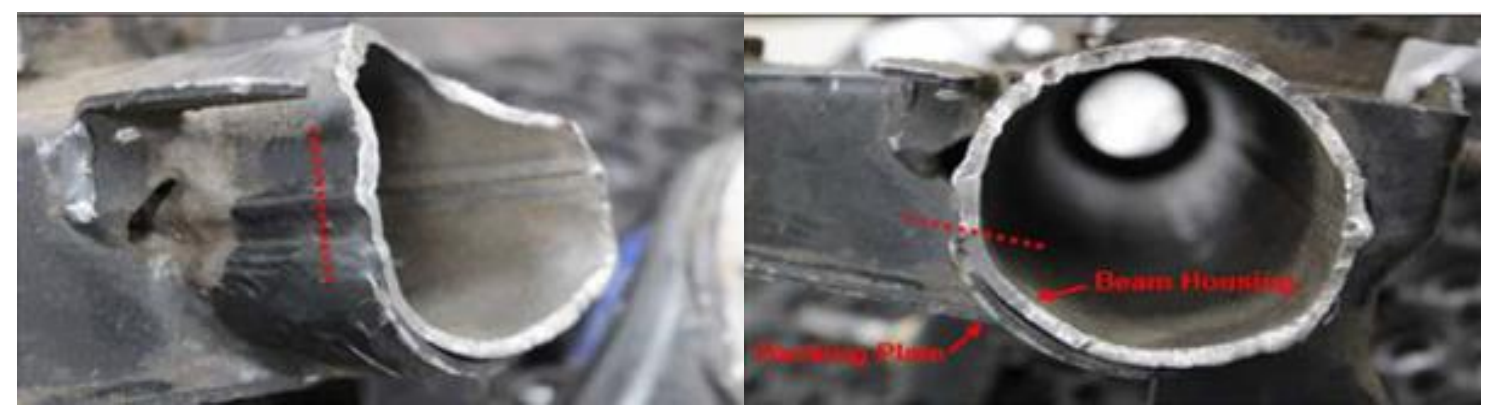

Figure 7 Side view of fracture and dotted line in red colour indicate sample section for weld analysis.

\subsection{Stress Level Measurements}

A Strain gauge is a sensor used to measure applied force. Its resistance varies with applied force. The force, pressure, tension, weight, etc., is converted into an electrical resistance that can then be measured. External forces result in stress and/or strain when applied to an object.

Strain gauges were mounted on the rear axle housing, to calculate the stresses in the rear axle housing Mounting position was shown by the red circles in table 5. Following are the mechanical properties of the base material of rear axle housing (BSK-46) [9].

Table 5 Mechanical properties of base material (BSK-46) [9].

\begin{tabular}{|c|c|c|c|}
\hline Specification & YS (MPa) (min) & TS (MPa) (min) & Elongation\% (min) \\
\hline BSK-46 & 451 & $490-627$ & 21 \\
\hline
\end{tabular}

Contact stresses calculated as ,

Stress = Young's Modulus / Strain .

Therefore, stress at left side as $261.58 \mathrm{MPa}$ and right side as $216 \mathrm{MPa}$.

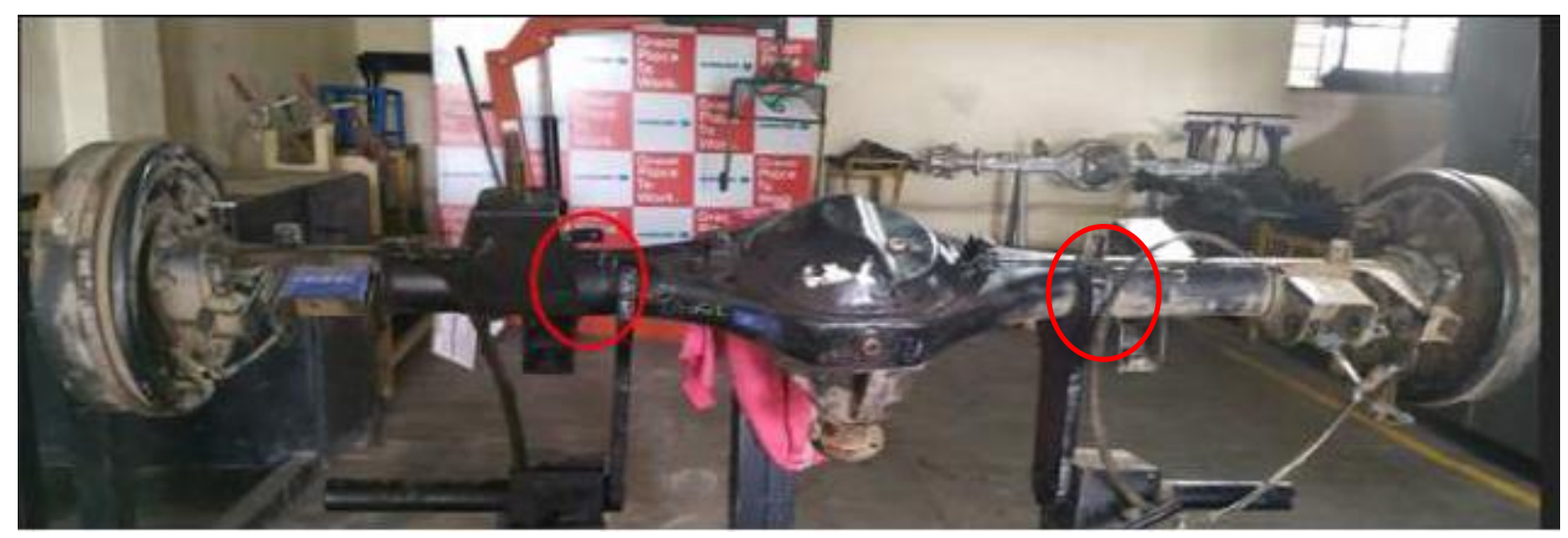

Figure 8 Mounting of strain gauges on axle housing to measure contact stresses

Strain gauges mounting position were shown by the red circles in the fig. 8 . With this strain gauge arrangement, stress values received in the running condition on the rear axle housing.

\section{FINITE ELEMENT ANALYSIS OF REAR AXLE HOUSING}

Using Finite Elements Analysis (FEA) it is possible to find the locations of high stresses suffered by the analysed element and their values. Specific conclusions can be drawn in this 
way and reach possible solutions to avoid the recurrence of these kinds of failures. In this analysis the rear axle housing was geometrically modelled as shown in Fig. 9. Hexagonal elements with a size of $2 \mathrm{~mm}$ were used in the FE mesh. The mesh had a total of 25277 elements. The size of the elements and mesh were selected after performing a series of iterations with the same loads and using different mesh sizes. It was noted from the iterations that the values of the stresses in the element varied considerably, for elements smaller than 2 $\mathrm{mm}$, making it high values related to singularities caused by small elements. For elements bigger than $2 \mathrm{~mm}$ the stresses were not representative as the size of the elements were higher than the contact region.

Following are the loading, boundary, and contact conditions of the model:

1. A fixed contact in zone A (end of the rear axle housing)

2. Lateral load B \& C, assumed constant in this analysis to simplify the modelling, with a value of $5100 \mathrm{~N}$ and applied on the back plate.

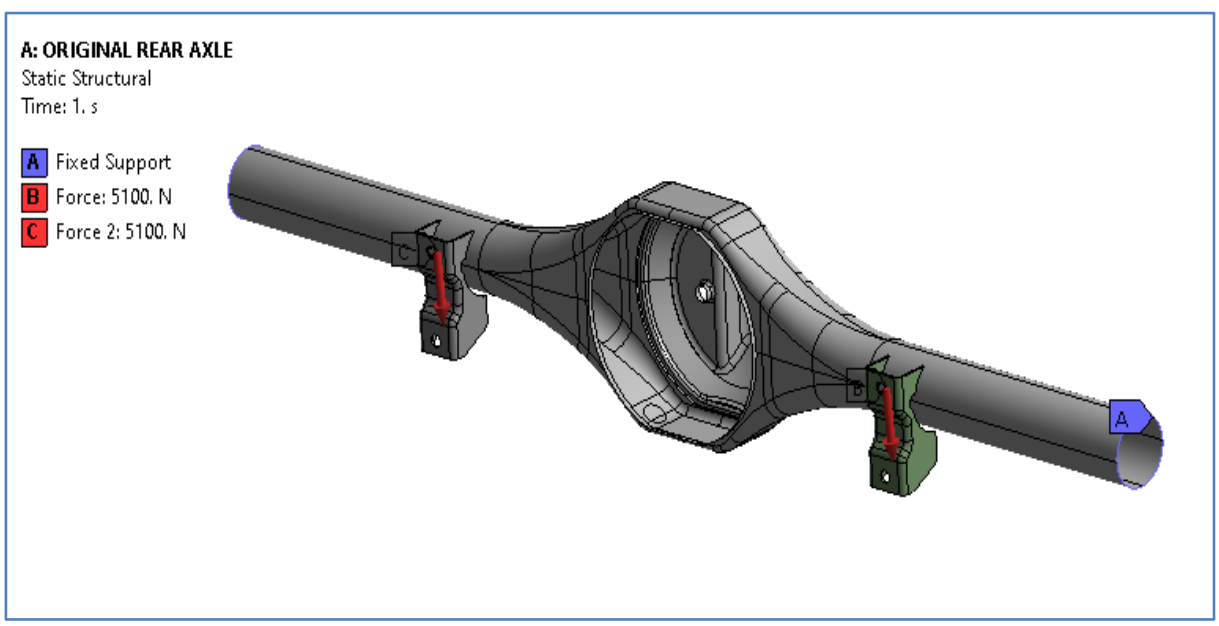

Figure 9 Loading condition in ANSYS

The analysis and calculations of maximum stresses were performed with and without the back plate, in order to highlight the places of higher stresses in the element. It is observed that there is no major change in the readings after removing the jack mounting plate from the welding joint. After this trial the trial by changing the thickness of the material from $3.5 \mathrm{~mm}$ to $3.7 \mathrm{~mm}, 4 \mathrm{~mm}$ and $4.2 \mathrm{~mm}$.

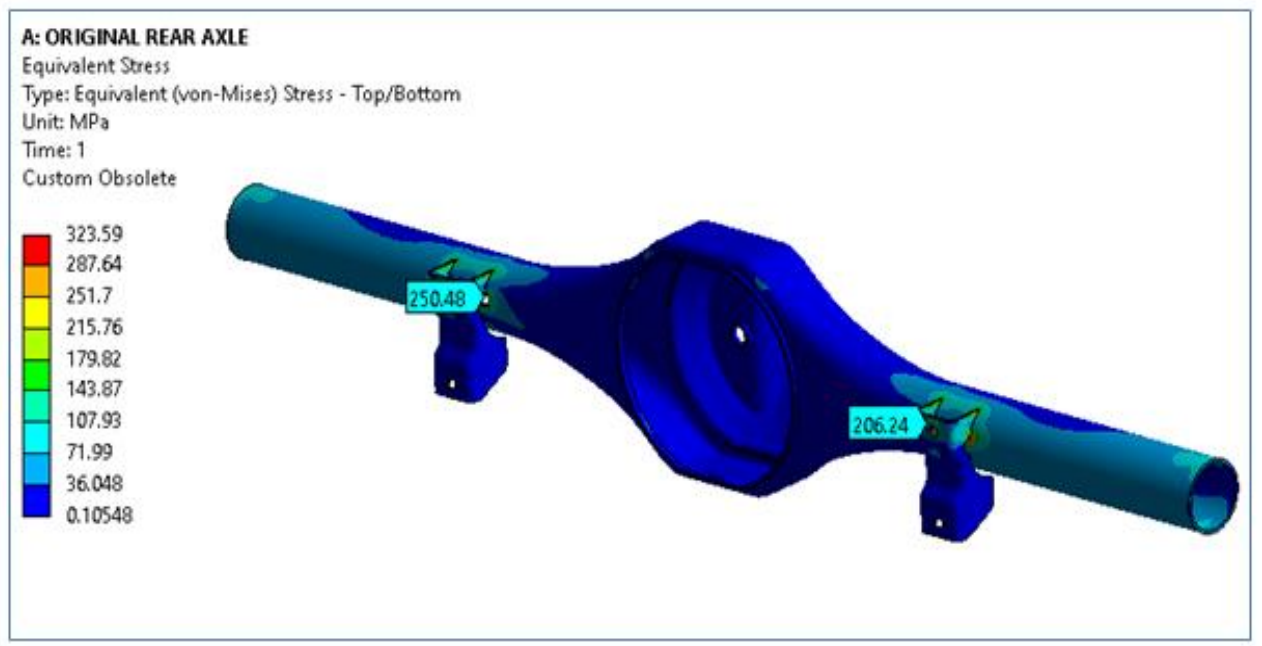

Figure 10 Von Mises stress plot for $3.5 \mathrm{~mm}$ thickness 
Fig. 10 shows the stress distribution of original rear axle housing with $3.5 \mathrm{~mm}$ thickness. Left side stress distribution $(250.48 \mathrm{MPa})$ is higher than the right-side stress distribution (206.24 MPa) by $21 \%$.

For analysis increased the thickness from $3.5 \mathrm{~mm}$ to $3.7 \mathrm{~mm}$ and it was giving following which is shown in Fig. 11

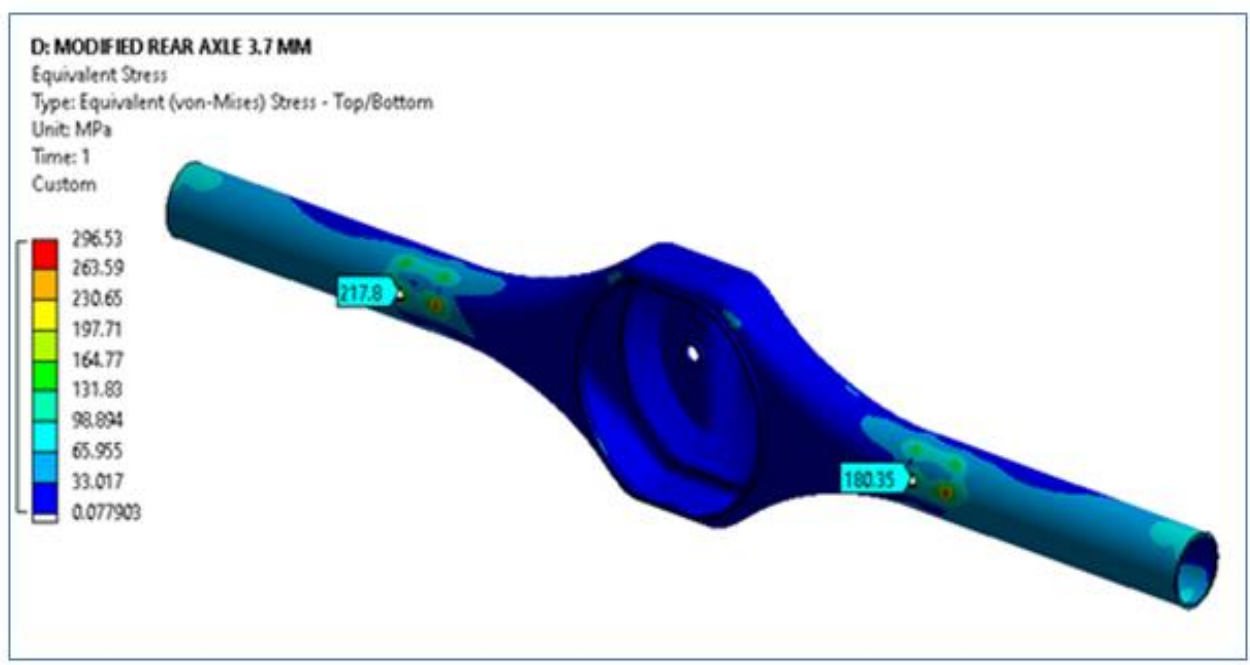

Figure 11 Von Mises stress plot for $3.7 \mathrm{~mm}$ thickness

Left side stress distribution reduced up to 217.8 MPa from 250.48 MPa and right side stress distribution reduced up to $180.35 \mathrm{MPa}$ from 206.24 MPa. The thickness from $3.7 \mathrm{~mm}$ to $4 \mathrm{~mm}$ and it is giving following which are shown in Fig. 12

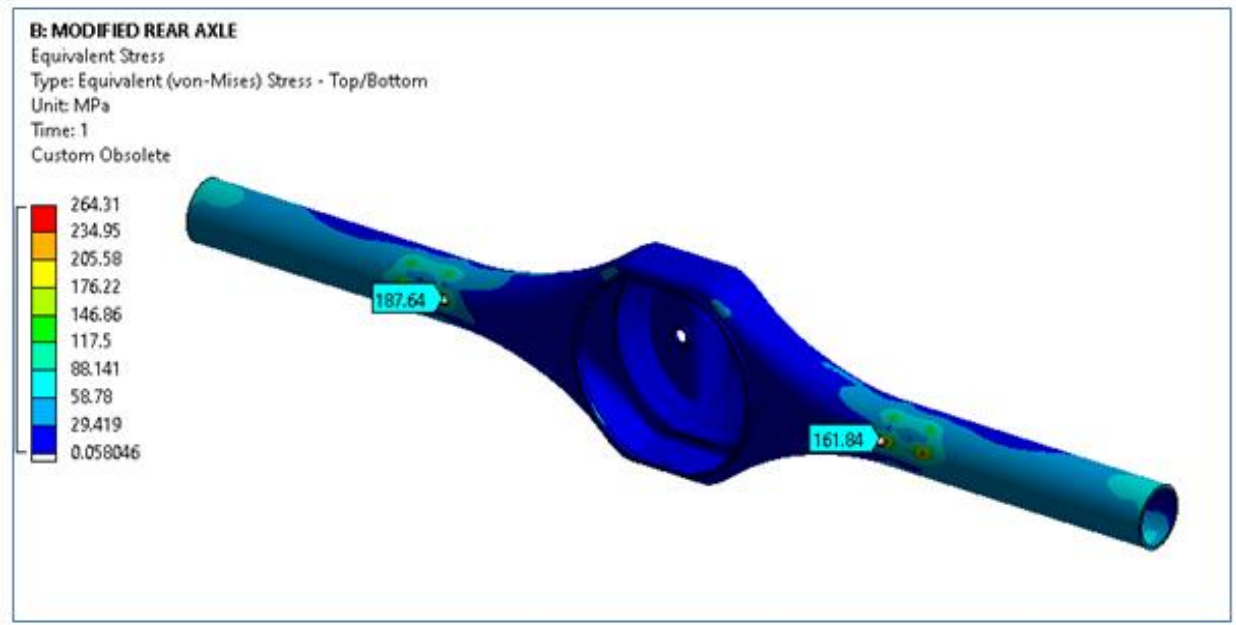

Figure 12 Von Mises stress plot for $4 \mathrm{~mm}$ thickness

Left side stress distribution reduced up to 187.64 MPa from 217.8 MPa and right side stress distribution reduced up to $161.84 \mathrm{MPa}$ from $180.35 \mathrm{MPa}$. The thickness from $4 \mathrm{~mm}$ to $4.2 \mathrm{~mm}$ and it was giving which is shown in Fig. 13 


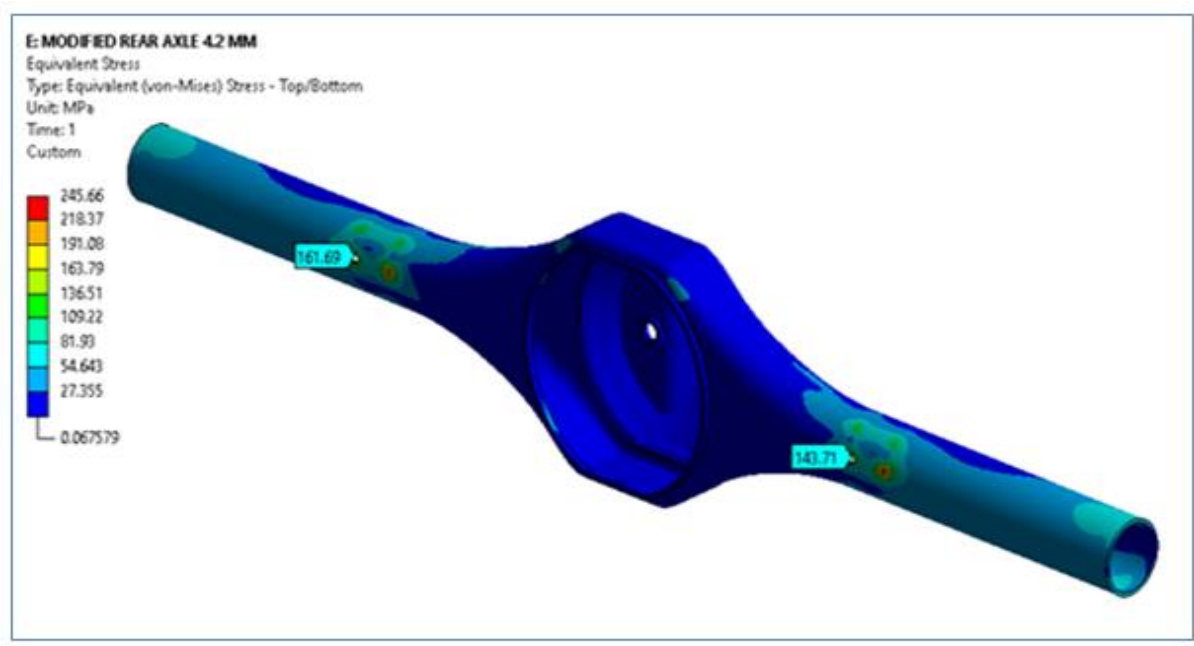

Figure 13 Von Mises stress plot for $4.2 \mathrm{~mm}$ thickness

Left side stress distribution reduced up to $161.69 \mathrm{MPa}$ from 187.64 MPa and right side stress distribution reduced up to $143.71 \mathrm{MPa}$ from 161.84 MPa.

Table 6 Comparison of experimental and numerical results

\begin{tabular}{|c|c|c|c|}
\hline S.No. & $\begin{array}{c}\text { Contact stresses on rear axle } \\
\text { housing with strain gauges } \\
(\mathbf{M P a})\end{array}$ & $\begin{array}{c}\text { Contact stresses on rear axle } \\
\text { housing for 3.5 mm thickness } \\
\text { with FEA (MPa) }\end{array}$ & Percent error \\
\hline 1 & 261.58 & 250 & $4.42 \%$ \\
\hline 2 & 216 & 206.4 & $4.44 \%$ \\
\hline
\end{tabular}

The comparison of experimental and numerical results is carried out and is shown in Table 6. The FEA results are compared with the physical test results showing 5\% error in both results which is negligible.

Table 7 Percent decrease in stress with respect to the original stress based on finite element analysis.

\begin{tabular}{|c|c|c|c|}
\hline Housing Thickness & $\begin{array}{c}\text { Left side Von } \\
\text { mises stress }\end{array}$ & $\begin{array}{c}\text { Right side Von } \\
\text { mises stress }\end{array}$ & $\begin{array}{c}\text { Percentage decrease } \\
\text { in stress with respect } \\
\text { to 3.5 mm thickness }\end{array}$ \\
\hline 3.5 & 250.48 & 206.24 & NA \\
\hline 3.7 & 217.8 & 180.34 & $13 \%$ \\
\hline 4 & 187.64 & 161.84 & $24 \%$ \\
\hline 4.2 & 161.69 & 143.71 & $33 \%$ \\
\hline
\end{tabular}

Table 7 shows when thickness was $3.5 \mathrm{~mm}$, left side contact stress was $250.48 \mathrm{MPa}$ and right side contact stress was $206.24 \mathrm{MPa}$ at which axle housing was failed. To avoid the failure, axle housing thickness was increased from $3.5 \mathrm{~mm}$ to $3.7 \mathrm{~mm}, 4 \mathrm{~mm} \& 4.2 \mathrm{~mm}$ and get the respective left side and right side contact stress values. When thickness increased to $3.7 \mathrm{~mm}$, contact stresses decreased by $13 \%$ but $3.7 \mathrm{~mm}$ thickness material is not available in market. Hence, $3.7 \mathrm{~mm}$ thickness is not feasible from production point of view. Then thickness increased to $4.2 \mathrm{~mm}$ and contact stresses decreased by $33 \%$. If $4.2 \mathrm{~mm}$ thickness material used for production it will increase the weight of the axle housing by $20 \%$ which will affect the vehicle performance. So, $4.2 \mathrm{~mm}$ thickness is not acceptable. Then thickness changed to $4 \mathrm{~mm}$ and checked contact stresses, which was decreased by $24 \%$ and weight 
increased by $14 \% .4 \mathrm{~mm}$ thick raw material is also available in market. Hence from cost, manufacturing and performance wise $4 \mathrm{~mm}$ thickness is the optimized thickness. Therefore, 4 $\mathrm{mm}$ thickness for rear axle housing is proposed.

\section{CONCLUSION}

The failed rear axle housing of a utility vehicle is studied to check its integrity which includes visual examination, chemical analysis, photo documentation, micro hardness test, and metallographic tests to evaluate the failure. Spectrum analysis and micro-hardness measurement revealed that the failed axle housing material was BSK-46 steel. The composition, microstructure, hardness values of the raw metal were found to be satisfactory and within the specification. The fracture initiated at the weld joint between back plate and rear axle housing, where a stress concentration was created.

The material used in the manufacture of the rear axle housing was appropriate for this kind of application. However, less thickness of the rear axle housing element allows the formation of stress concentrators which further reduce the life of the element. Therefore, the causes of the failure of the rear axle housing was due to Defective geometric design of the element thickness.

In order to reduce the contact stresses on the rear axle housing element, a change on the geometric design of the element was proposed. FEA done on $3.7 \mathrm{~mm}, 4 \mathrm{~mm}$ and $4.2 \mathrm{~mm}$ thickness. Finally, $4 \mathrm{~mm}$ thickness was selected. This was an optimised thickness from manufacturing, cost and vehicle performance. Therefore, in the proposed design, thickness of the rear axle housing beam was increased by $0.5 \mathrm{~mm}$. This element was modelled using the same loading and boundary conditions employed for the failed element. In the proposed case the maximum stresses were found on the section of the element, with a maximum value of 187.64 MPa approximately (24\% improved as compared to the original one).

Finally, it is suggested to modify the geometry of the rear axle housing to reduce the contact stresses and avoid such types of failures.

\section{REFERENCES}

[1] S. Raut and L. Raut, "A Review of Various Techniques Used for Shaft Failure Analysis", International Journal of Engineering Research and General Science, Vol.2, Issue 2,2014.

[2] Souvik Das, Goutam Mukhopadhyay, Sandip Bhattacharyya, "Failure analysis of axle shaft of a fork lift" Case Studies in Engineering Failure Analysis, Vol. 3, Pp. 46-51, 2015.

[3] Khairul Akmal Shamsuddin, Mohd Syamil Tajuddin, Megat Mohd Amzari Megat Mohd Aris, Mohd Nurhidayat Zahelem, "Stress Distribution Analysis of Rear Axle Housing by using Finite Elements Analysis", The International Journal of Engineering and Science, Vol, 3, Issue, 10, 2014.

[4] F Mujahidin and Andoko, "Stress Analysis of Rear Axle Pick-up with Finite Element Method", International Conference on Mechanical Engineering Research and Application, 2019.

[5] G.K. Nanawarea, M.J. Pable, "Failures of rear axle shafts of 575 DI tractors" Engineering Failure Analysis, Vol. 10, Issue 6, Pp. 719-724, 2003.

[6] Osman Asi, "Fatigue failure of a rear axle shaft of an automobile", Engineering Failure Analysis, Vol. 13, Pp.1293-1302, 2006 
Failure Analysis of Rear Axle (Banjo Beam) housing of a Utility Vehicle

[7] M.M. Topac, H. Gunal, N.S. Kuralay, "Fatigue failure prediction of a rear axle housing prototype by using finite element analysis", Engineering Failure Analysis 16 (2009) 14741482.

[8] IS-228-1997 Indian Standard Methods for Chemical Analysis of Steels.

[9] ASM metals handbook. Fatigue and fracture, vol. 19. Metals Park (OH): American Society for Metals; 1996 